\title{
PReS-FINAL-2224: Canakinumab treatment regimens in CAPS-patients
}

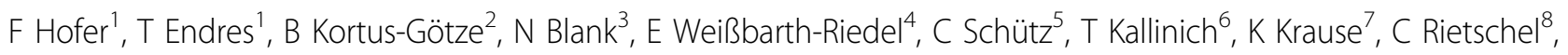 \\ G Horneff $^{9}$, J Kuemmerle-Deschner ${ }^{1 *}$ \\ From 20th Pediatric Rheumatology European Society (PReS) Congress \\ Ljubljana, Slovenia. 25-29 September 2013
}

\begin{abstract}
Introduction
Canakinumab is a recombinant monoclonal fully human antibody against Interleukin- $1 \beta$ and approved for the treatment of CAPS in many countries including Europe and the US. Current dose recommendations are $150 \mathrm{mg}$ (body weight $>40 \mathrm{~kg}$ ) respectively $2 \mathrm{mg} / \mathrm{kg}$ body weight (15 to $40 \mathrm{~kg}$ ) every 8 weeks but yield insufficient response in some individuals, especially in children and patients with severe phenotypes [1].
\end{abstract}

\section{Objectives}

In this study we analyzed the response to daily practice (in contrast to trial condition) canakinumab treatment regimens in CAPS patients with focus on age, mutation and clinical presentation and the necessity and effect of dose adjustment.

\section{Methods}

An observational national multicenter study was conducted. CAPS patients were included if they received at least two doses of canakinumab. Data included information regarding demographics, treatment, clinical disease activity and inflammatory markers (including SAA, CRP, ESR, IL-6). Response to treatment was assessed using CAPS-disease activity scores, CRP and/or SAA levels.

\section{Results}

A cohort of 68 patients with CAPS was analyzed. Median age was 25.4 years (range 22 months to 73 years). When treatment was initiated, 27 patients had been younger than 18 years. The most frequent mutations

${ }^{1}$ Department of Pediatrics, Division of Pediatric Rheumatology, University Hospital Tuebingen, Tuebingen, Germany

Full list of author information is available at the end of the article were R260W, A439V, E311K, V198M, Q703K and most patients showed MWS or FCAS/MWS phenotype (3 patients with NOMID, 4 with MWS/NOMID). The median treatment duration was 855 days (range: 281973 days). In 39 patients (57\%) full response was sustained until the next scheduled drug application (34\% (23 patients) partial remission). With standard treatment 21 patients $(31 \%)$ achieved full response. In 30 patients (44\%) canakinumab dose and/or application interval was increased above the standard regimen (2/3 NOMID, 3/4 MWS/NOMID). Neither laboratory parameters nor clinical disease activity at the beginning of treatment were able to predict the necessity to adjust treatment regimen. Two serious adverse events were reported (severe infection, osteonecrosis), mild and moderate adverse events were mostly upper respiratory tract infections but almost no injection site reactions.

\section{Conclusion}

Most CAPS patients achieve full remission with canakinumab. However, almost $50 \%$ of patients, particularly children, require dose adjustment. Full remission by dose increase was achieved without an increased rate of adverse events. Individual adjustment of therapy should be performed as needed as predictive parameters are lacking.

\section{Disclosure of interest}

F. Hofer: None declared, T. Endres: None declared, B. Kortus-Götze: None declared, N. Blank: None declared, E. Weißbarth-Riedel: None declared, C. Schütz: None declared, T. Kallinich: None declared, K. Krause: None declared, C. Rietschel: None declared, G. Horneff: None declared, J. Kuemmerle-Deschner Grant/ Research Support from: NOVARTIS, Consultant for: NOVARTIS, SOBI. 


\section{Authors' details}

'Department of Pediatrics, Division of Pediatric Rheumatology, University Hospital Tuebingen, Tuebingen, Germany. ${ }^{2}$ Klinik für Innere Medizin, Klinikum der Philipps-Universität Marburg, Marburg, Germany.

${ }^{3}$ Hämatologie, Onkologie u. Rheumatologie, Universitätsklinikum Heidelberg, Heidelberg, Germany. ${ }^{4}$ Kinderrheumatologische Ambulanz,

Universitätsklinikum Eppendorf, Hamburg, Germany. ${ }^{5}$ Klinik für Kinder und Jugendmedizin, Universitätsklinikum UIm, Ulm, Germany.

${ }^{6}$ Kinderklinik Sektion Rheumatologie, Charité Campus Virchow, Berlin,

Germany. " „Allergie-Centrum Charité", Klinik für Dermatologie, Charité Campus Mitte, Berlin, Germany. ${ }^{8}$ Kinder-und Jugendrheumatologie,

Clementine-Kinderhospital, Frankfurt, Germany. ${ }^{9}$ Abteilung für Allgemeine Kinder-und Jugendmedizin, Asklepios-Klinik Sankt Augustin, Sankt Augustin, Germany.

Published: 5 December 2013

\section{Reference}

1. Kuemmerle-Deschner JB, et al: Two years results from an open-label, multicentre, phase III study evaluating the safety and efficacy of canakinumab in patients with cryopyrin-associated periodic syndrome across different severity phenotypes. Ann Rheum Dis 2011, 70:2095-2102.

doi:10.1186/1546-0096-11-S2-P214

Cite this article as: Hofer et al:: PReS-FINAL-2224: Canakinumab treatment regimens in CAPS-patients. Pediatric Rheumatology 2013 11(Suppl 2):P214.

\section{Submit your next manuscript to BioMed Central} and take full advantage of:

- Convenient online submission

- Thorough peer review

- No space constraints or color figure charges

- Immediate publication on acceptance

- Inclusion in PubMed, CAS, Scopus and Google Scholar

- Research which is freely available for redistribution

Submit your manuscript at www.biomedcentral.com/submit
Ciomed Central 